\title{
On the immature stages of the crazy ant Paratrechina longicornis (Latreille 1802) (Hymenoptera: Formicidae)
}

\author{
EDUARDO GONÇALVES PATERSON FOX ${ }^{1}$, DANIEL RUSS SOLIS ${ }^{1}$, CARLOS MASSURETTI DE \\ JESUS $^{1}$, ODAIR CORREA BUENO ${ }^{1}$, ANTONIO TENIYOSHI YABUKI ${ }^{1} \&$ MÔNICA LANZONI ROSSI ${ }^{2}$ \\ ${ }^{1}$ Departamento de Biologia / UNESP. Address: 24A Avenue 1515 - Bela Vista CEP 13506-900 - Rio Claro, SP - Brazil. \\ E-mails (in order of appearance): ofoxofox@gmail.com; entomo75@yahoo.com; massuretti@gmail.com; odaircb@rc.unesp.br \\ ${ }^{2}$ Laboratório de Histopatologia Vegetal / USP. Address: Centenário Avenue 303 - CEP 13400-970 -Piracicaba - SP - Brazil. \\ E-mail:monicalr@cena.usp.br
}

\begin{abstract}
The ant Paratrechina longicornis is a cosmopolitan ant species that has been accidentally spread by commerce around the world, and now is a pest of houses and hospitals. The morphology of its larval stages has been previously described without knowledge of the number of instars. The present study revisits the original description of $P$. longicornis larvae by adding differences observed among the three larval instars. Compared to other Paratrechina species studied so far, $P$. longicornis presents smaller larvae, less evident variation in mandible morphology, and clear variation in the morphology of head hairs between the analysed specimens of the second and third instar larvae. Ultrastructural images of the eggs, larval spiracle ornamentation, and pupae are also presented for the first time.
\end{abstract}

Key words: ant, morphology, larval instars, Formicinae, Paratrechina longicornis

\section{Introduction}

The genus Paratrechina Motschulsky comprises about 118 described species, some of which have been spread throughout the world by commerce, becoming important invasive pest ants in buildings (e.g. houses and hospitals) of many countries. The most economically important species of the genus in the Americas are Paratrechina bourbonica (Forel), Paratrechina fulva (Mayr), Paratrechina longicornis (Latreille) and Paratrechina vividula (Nylander) (Trager 1984). In Brazil, the species P. longicornis is regarded as a mechanical carrier of pathogenic microorganisms in hospital environments (Bueno \& Fowler 1994; Zarzuela et al. 2005). In spite of the pest relevance of the genus, there are still few studies of their biology in tropical regions.

The importance of larval descriptions to myrmecology has been emphasized by Wheeler \& Wheeler (1976; 1986), who have in fact described the larvae of over 700 ant species. One of their conclusions is that certain larval characters may be applied to species level taxonomy and systematics in various ant genera.

Some of these characters have been recently applied to phylogenetic studies (Schultz \& Meier 1995; Pitts 2005), but for the vast majority of ant species — some 11,000 species (Agosti \& Johnson 2005) — larval descriptions are unknown or were rather superficially described based on few specimens. Furthermore, deeper knowledge of immature morphology is also of crucial relevance in clarifying many aspects of ant biology and their social organization.

The larvae of P. longicornis have been previously described by Wheeler \& Wheeler (1986), although without the knowledge of the number of larval instars and based only on five specimens. In this context, the present study aims at revisiting the original description armed with the knowledge of the number of larval 